\title{
Synthesis and molecular structures of monooxo aryl complexes of osmium(VI)
}

\author{
Man-Kit Lau, Joyce L.C. Chim, Wing-Tak Wong, lan D. Williams, and \\ Wa-Hung Leung
}

\begin{abstract}
Reaction of $\left[\mathrm{OsO}_{4}\right]$ with $\mathrm{C}_{7} \mathrm{H}_{7} \mathrm{MgBr}\left(\mathrm{C}_{7} \mathrm{H}_{7}=2\right.$-methylphenyl) followed by column chromatography afforded the reported osmium tetraaryl $\left[\mathrm{Os}\left(\mathrm{C}_{7} \mathrm{H}_{7}\right)_{4}\right]$ along with the oxo-osmium(VI) $\left(\left[\mathrm{OsO}\left(\mathrm{C}_{7} \mathrm{H}_{7}\right)_{4}\right]\right)(1)(13 \%)$ and the dioxoosmium(VI) $\left(\left[\mathrm{OsO}_{2}\left(\mathrm{C}_{7} \mathrm{H}_{7}\right)_{2}\right]\right)(2)(25 \%)$ complexes. Treatment of $\left[\mathrm{OsO}_{4}\right]$ with $\mathrm{C}_{8} \mathrm{H}_{9} \mathrm{MgBr}\left(\mathrm{C}_{8} \mathrm{H}_{9}=2,5\right.$-dimethylphenyl) gave a mixture of $\left[\mathrm{Os}\left(\mathrm{C}_{8} \mathrm{H}_{9}\right)_{4}\right](3)(34 \%)$ and $\left[\mathrm{OsO}\left(\mathrm{C}_{8} \mathrm{H}_{9}\right)_{4}\right](4)(4 \%)$ while that with $\mathrm{C}_{8} \mathrm{H}_{9} \mathrm{OMgBr}\left(\mathrm{C}_{8} \mathrm{H}_{4} \mathrm{O}=4-\right.$ methoxy-2-methylphenyl) afforded $\left[\mathrm{OsO}\left(\mathrm{C}_{8} \mathrm{H}_{9} \mathrm{O}\right)_{4}\right](5)$ in $20 \%$ yield. Oxidation of 3 with 3-chloroperoxybenzoic acid afforded 4 in good yield. The solid-state structures of 1 and 4 have been established by X-ray crystallography. Crystals of 1 are tetragonal with $a=13.080(1)$ and $c=6.6506(5) \AA, V=1137.9(1) \AA^{3}, Z=2$, and space group of $P 4 / n$; while those of 4 are tetragonal with $a=13.593(2)$ and $c=7.377(2) \AA, V=1363.0(5) \AA^{3}, Z=4$, and space group of $P 4 / n$. The geometry around osmium in both complexes is square pyramidal with the oxo ligand occupying apical position. The Os-O and Os-C distances in 1 are $1.652(2)$ and $2.084(1) \AA$, respectively, while those in 4 are $1.688(7)$ and $2.088(4) \AA$, respectively. The cyclic voltammograms of the monooxo aryl osmium(VI) compounds show reversible $\mathrm{Os}(\mathrm{VI} / \mathrm{V})$ couple at around $-1.4 \mathrm{~V}$ vs. ferrocene/ferrocenium couple.
\end{abstract}

Key words: osmium(VI), oxo aryl complexes.

Résumé : La réaction du $\left[\mathrm{OsO}_{4}\right]$ avec du $\mathrm{C}_{7} \mathrm{H}_{7} \mathrm{MgBr}\left(\mathrm{C}_{7} \mathrm{H}_{7}=2\right.$-méthylphényle), suivie d'une chromatographie sur colonne permet d'isoler le tétraarylosmium attendu $\left[\mathrm{Os}\left(\mathrm{C}_{7} \mathrm{H}_{7}\right)_{4}\right]$ aux côtés de complexes oxo-osmium(VI) [OsO(C $\left.\left.\mathrm{C}_{7} \mathrm{H}_{7}\right)_{4}\right]$ (1) (13\%) et dioxo-osmium(VI) $\left[\mathrm{OsO}_{2}\left(\mathrm{C}_{7} \mathrm{H}_{7}\right)_{2}\right]$ (2) (25\%). Le réaction du $\left[\mathrm{OsO}_{4}\right]$ avec du $\mathrm{C}_{8} \mathrm{H}_{9} \mathrm{MgBr}\left(\mathrm{C}_{8} \mathrm{H}_{9}=2,5-\right.$ diméthylphényle) conduit à un mélange de $\left[\mathrm{Os}\left(\mathrm{C}_{8} \mathrm{H}_{9}\right)_{4}\right](3)(34 \%)$ et de $\left[\mathrm{OsO}\left(\mathrm{C}_{8} \mathrm{H}_{9}\right)_{4}\right](4)(4 \%)$ alors que celle avec $\mathrm{C}_{8} \mathrm{H}_{9} \mathrm{MgOBr}\left(\mathrm{C}_{8} \mathrm{H}_{9}=4\right.$-méthoxy-2-méthylphényle) conduit au $\left[\mathrm{OsO}\left(\mathrm{C}_{8} \mathrm{H}_{9} \mathrm{O}\right)_{4}\right](5)$ avec un rendement de $20 \%$. L'oxydation du produit 3 par de l'acide 3-chloroperbenzoïque conduit au produit 4 avec un bon rendement. Les structures des composés 1 et $\mathbf{4}$ ont été déterminées à l'état solide par diffraction des rayons $X$. Les cristaux de 1 sont tétragonaux, groupe d'espace $P 4 / n$, avec $a=13,080(1)$ et $c=6,6506(5) \AA, V=1137,9(1) \AA^{3}$ et $Z=2$ alors que ceux du composé 4 sont tétragonaux, groupe d'espace $P 4 / n$, avec $a=13,593(2)$ et $c=7,3776(2) \AA$ et $Z=4 V=1363,0(5) \AA^{3}$. Dans chacun des complexes, la géométrie autour de l'osmium est de type pyramide carrée de laquelle le ligand oxo se trouve en position apicale. Les distances $\mathrm{Os}-\mathrm{O}$ et $\mathrm{Os}-\mathrm{C}$ dans le composé 1 sont respectivement de $1,652(2)$ et $2,084(1) \AA$ alors que celles dans le composé 4 sont respectivement de 1,688(7) et 2,088(4) $\AA$. Dans les voltampérogrammes cycliques des composés monooxo aryl osmium(VI), on observe le couple réversible Os(VI/V) aux environs de $-1,4 \mathrm{~V}$ par rapport au couple ferrocène/ferrocénium.

Mots clés : osmium(VI), complexes oxo aryles.

[Traduit par la Rédaction]

\section{Introduction}

Organometallic oxides are of interest due to their relevance to the active intermediates in metal-catalyzed oxida-

Received August 30, 2000. Published on the NRC Research Press Web site at http://canjchem.nrc.ca on July 2, 2001.

This paper is dedicated to Professor Brian R. James on the occasion of his $65^{\text {th }}$ birthday.

M.-K. Lau, J.L.C. Chim, I.D. Williams, and W.-H.

Leung. ${ }^{1}$ Department of Chemistry, The Hong Kong

University of Science and Technology, Clear Water Bay,

Kowloon, Hong Kong, China.

W.-T. Wong. Department of Chemistry, The University of Hong Kong, Pokfulam Road, Hong Kong, China.

${ }^{1}$ Corresponding author (e-mail: chleung@ust.hk). tion of organic compounds $(1,2)$. Some transition metal oxo alkyls, notably $\left[\operatorname{Re}\left(\mathrm{CH}_{3}\right) \mathrm{O}_{3}\right]$, are also used as stoichiometric and catalytic reagents for organic transformations (2). While oxo alkyls of oxophilic early transition metals are welldocumented, there are relatively few examples of the later transition-metal congeners. Wilkinson and co-workers $(3,4)$ first reported the synthesis of high-valent osmium aryls and oxo aryls by arylation of $\left[\mathrm{OsO}_{4}\right]$ with Grignard reagents $\mathrm{ArMgBr}(\mathrm{Ar}=\operatorname{aryl})$. It was found that the ortho-methyl substituent in Ar has a significant effect on the nature of the arylation products. Thus, reaction of $\left[\mathrm{OsO}_{4}\right]$ with diorthosubstituted mesMgBr (mes = 2,4,6-trimethylphenyl) afforded $\left.\left[\mathrm{OsO}_{2} \text { (mes) }\right)_{2}\right]$ (3) whereas interactions of $\left[\mathrm{OsO}_{4}\right]$ with monoortho-substituted or unsubstituted $\mathrm{ArMgBr}$ (e.g., $\mathrm{Ar}=$ 2-methylphenyl or phenyl) gave homoleptic Os(IV) aryls $\left[\mathrm{Os}(\mathrm{Ar})_{4}\right]$ (4). However, to our knowledge, no oxo(tetraaryl)osmium(VI) complexes have been isolated al- 
though oxo(tetraalkyl)osmium(VI) complexes have been prepared by alkylation of $\left[\mathrm{OsO}_{4}\right]$ (5) or oxo-osmium glycolates (6). In view of the low yield for the synthesis of $\left[\mathrm{Os}\left(\mathrm{C}_{7} \mathrm{H}_{7}\right)_{4}\right]$, we suspect that there may be other unidentified product(s) for the arylation of $\left[\mathrm{OsO}_{4}\right]$. To this end, we set out to reinvestigate the reaction between $\left[\mathrm{OsO}_{4}\right]$ and $\mathrm{ArMgBr}$, and to separate the products by column chromatography. We here describe the isolation, molecular structures, and electrochemistry of the first monooxo aryl complexes of osmium(VI).

\section{Experimental}

All manipulations, unless otherwise stated, were carried out in air. Solvents were purified, dried, and distilled prior to use. $\left[\mathrm{OsO}_{4}\right]$ was obtained from Strem Ltd. $\mathrm{ArMgBr}$ in $\mathrm{Et}_{2} \mathrm{O}$ were prepared from commercially available aryl bromides and $\mathrm{Mg}$.

Spectrometers used were as follows: IR spectra (in $\mathrm{KBr}$ discs) PerkinElmer 16 PC FT IR; mass spectra on a Finnigan TSQ 7000; UV-vis spectra Milton-Roy Spectronic 3000 diode array; $300 \mathrm{MHz}{ }^{~} \mathrm{H}$ NMR spectra Bruker ALX 300 (chemical shifts in ppm relative to $\mathrm{SiMe}_{4}$ ). Cyclic voltammetry was performed with a Princeton Applied Research (PAR) Model 273A potentiostat. The working and reference electrodes were glassy carbon and $\mathrm{Ag} / \mathrm{AgNO}_{3}$ ( $0.1 \mathrm{M}$ in acetonitrile), respectively, and the scan rate was $100 \mathrm{mV} \mathrm{s}^{-1}$. Formal potentials $\left(E_{1 / 2}\right)$ were measured in $\mathrm{CH}_{2} \mathrm{Cl}_{2}$ solutions with $0.1 \mathrm{M}\left[n-\mathrm{NBu}_{4}\right]\left[\mathrm{PF}_{6}\right]$ as supporting electrolyte and reported with reference to the ferrocenium/ferrocene couple $\left(\mathrm{Cp}_{2} \mathrm{Fe}^{+/ 0}\right)$. Elemental analyses were performed by Medac Ltd., Surrey, U.K.

\section{$\left[\mathrm{OsO}\left(\mathrm{C}_{7} \mathrm{H}_{7}\right)_{4}\right](1)$ and $\left[\mathrm{OsO}_{2}\left(\mathrm{C}_{7} \mathrm{H}_{7}\right)_{2}\right](2)\left(\mathrm{C}_{7} \mathrm{H}_{7}=2\right.$ - methylphenyl)}

These complexes were synthesized using a modification of the Wilkinson's procedure. To a solution of $\left[\mathrm{OsO}_{4}\right](1 \mathrm{~g}$, $3.94 \mathrm{mmol})$ in THF $(30 \mathrm{~mL})$ at $-78^{\circ} \mathrm{C}$ were added 7 equiv of 2-methylphenylmagnesium bromide $(17.3 \mathrm{~mL}$ of a $1.6 \mathrm{M}$ solution in $\mathrm{Et}_{2} \mathrm{O}$ ), and the mixture was stirred for $45 \mathrm{~min}$. The resulting purple mixture was then warmed to room temperature, stirred for a further $2 \mathrm{~h}$, and evaporated to dryness. The residue was extracted into $\mathrm{CH}_{2} \mathrm{Cl}_{2}$ in air and subjected to column chromatography (silica gel). Elution with hexane, $\mathrm{CH}_{2} \mathrm{Cl}_{2}$-hexane (1:4), and acetone afforded purple $\left[\mathrm{Os}\left(\mathrm{C}_{7} \mathrm{H}_{7}\right)_{4}\right](10 \%)$, orange $1(13 \%)$, and green $2(25 \%)$, respectively. Recrystallization of $\mathbf{1}$ from $\mathrm{CH}_{2} \mathrm{Cl}_{2}$-hexane led to isolation of orange blocks, which were suitable for $\mathrm{X}$-ray diffraction.

\section{Characterization data for $\mathbf{I}$}

FT IR $\left(\mathrm{KBr}, \mathrm{cm}^{-1}\right)$ : $986(\mathrm{Os}=\mathrm{O})$. FAB-MS m/z: $572\left(\mathrm{M}^{+}\right)$. ${ }^{1} \mathrm{H}$ NMR $\left(300 \mathrm{MHz}, \mathrm{CDCl}_{3}\right) \delta: 2.32\left(\mathrm{~s}, 12 \mathrm{H}, \mathrm{CH}_{3}\right), 5.96(\mathrm{~d}$, $\left.J=7.6 \mathrm{~Hz}, 4 \mathrm{H}, \mathrm{H}_{o}\right), 6.87\left(\mathrm{t}, J=7.6 \mathrm{~Hz}, 4 \mathrm{H}, \mathrm{H}_{m}\right), 6.96(\mathrm{t}$, $\left.J=7.6 \mathrm{~Hz}, 4 \mathrm{H}, \mathrm{H}_{p}\right), 7.27\left(\mathrm{~d}, J=7.6 \mathrm{~Hz}, 4 \mathrm{H}, \mathrm{H}_{m}{ }^{\prime}\right) . E_{1 / 2}(\mathrm{~V}):$ $-1.41[\mathrm{Os}(\mathrm{VI} / \mathrm{V})]$. Anal. calcd. for $\mathrm{C}_{28} \mathrm{H}_{28} \mathrm{OOs}$ : C 59.0, $\mathrm{H}$ 4.9; found: C 58.3 , H 4.9.

\section{Characterization data for 2}

FT IR $\left(\mathrm{KBr}, \mathrm{cm}^{-1}\right): 912,956\left(\mathrm{OsO}_{2}\right)$. FAB-MS $\mathrm{m} / \mathrm{z}: 407$ $[\mathrm{M}+1]^{+}$. UV-vis $\left(\mathrm{CH}_{2} \mathrm{Cl}_{2}\right) \lambda_{\max }(\mathrm{nm})\left(\varepsilon_{\max }\left(\mathrm{M}^{-1} \mathrm{~cm}^{-1}\right)\right): 248$
(23000), 350 (8700). ${ }^{1} \mathrm{H}$ NMR ( $300 \mathrm{MHz}, \mathrm{CDCl}_{3}$ ) $\delta: 2.57$ $\left(\mathrm{s}, 6 \mathrm{H}, \mathrm{CH}_{3}\right), 7.04-7.13\left(\mathrm{~m}, 4 \mathrm{H}, \mathrm{H}_{m}\right.$ and $\left.\mathrm{H}_{p}\right), 7.19(\mathrm{~d}, J=7.8$ $\left.\mathrm{Hz}, 2 \mathrm{H}, \mathrm{H}_{o}\right), 7.40\left(\mathrm{~d}, J=7.8 \mathrm{~Hz}, 2 \mathrm{H}, \mathrm{H}_{m}^{\prime}\right) \cdot E_{1 / 2}(\mathrm{~V}):-1.14$ [Os(VI/V)]. Anal. calcd. for $\mathrm{C}_{14} \mathrm{H}_{14} \mathrm{O}_{2} \mathrm{Os}$ : C 41.6, H 3.5; found: C 41.3, H 3.9 .

\section{$\left[\mathrm{Os}\left(\mathrm{C}_{8} \mathrm{H}_{9}\right)_{4}\right](3)$ and $\left[\mathrm{OsO}\left(\mathrm{C}_{8} \mathrm{H}_{9}\right)_{4}\right](4)$}

To a solution of $\left[\mathrm{OsO}_{4}\right](0.5 \mathrm{~g}, 2.0 \mathrm{mmol})$ in $\mathrm{Et}_{2} \mathrm{O}$ $(20 \mathrm{~mL})$ at $-78^{\circ} \mathrm{C}$ were added 7 equiv of $2,5-$ dimethylphenylmagnesium bromide $(11.5 \mathrm{~mL}$ of a $1.2 \mathrm{M}$ solution in $\mathrm{Et}_{2} \mathrm{O}, 14 \mathrm{mmol}$ ) dropwise under nitrogen. The resulting reddish-brown mixture was warmed to room temperature, stirred for $2 \mathrm{~h}$, and evaporated to dryness. The dark yellow sticky residue was extracted into $\mathrm{CH}_{2} \mathrm{Cl}_{2}$, filtered through a Celite pad, and subjected to column chromatography (silica gel). Elution with hexane and hexane- $\mathrm{Et}_{2} \mathrm{O}$ (7:3) afforded purple $3(34 \%)$ and orange $4(2 \%)$, respectively.

\section{Characterization data for 3}

FAB-MS m/z: $612\left(\mathrm{M}^{+}\right)$. ${ }^{1} \mathrm{H}$ NMR $\left(300 \mathrm{MHz}, \mathrm{CDCl}_{3}\right) \delta$ : $2.22\left(\mathrm{~s}, 12 \mathrm{H}, \mathrm{CH}_{3}\right), 2.27\left(\mathrm{~s}, 12 \mathrm{H}, \mathrm{CH}_{3}\right), 6.57(\mathrm{~d}, J=8.5 \mathrm{~Hz}$, $\left.4 \mathrm{H}, \mathrm{H}_{p}\right), 6.68\left(\mathrm{~d}, J=8.5 \mathrm{~Hz}, 4 \mathrm{H}, \mathrm{H}_{m}\right), 6.70\left(\mathrm{~s}, 4 \mathrm{H}, \mathrm{H}_{o}\right) . E_{1 / 2}$ (V): $-1.48[\mathrm{Os}(\mathrm{IV} / \mathrm{III})]$ and $0.24[\mathrm{Os}(\mathrm{V} / \mathrm{IV})]$. Anal. calcd. for $\mathrm{C}_{32} \mathrm{H}_{36}$ Os: C 62.9, H 5.9; found: C 63.0, H 6.0.

\section{Characterization data for 4}

FT IR $\left(\mathrm{KBr}, \mathrm{cm}^{-1}\right)$ : $986(\mathrm{Os}=\mathrm{O})$. FAB-MS $\mathrm{m} / z: 572\left(\mathrm{M}^{+}\right)$. UV-vis $\left(\mathrm{CH}_{2} \mathrm{Cl}_{2}\right) \lambda_{\max }(\mathrm{nm})\left(\varepsilon_{\max }\left(\mathrm{M}^{-1} \mathrm{~cm}^{-1}\right)\right): 248(22000)$, 350 (8250). ${ }^{1} \mathrm{H}$ NMR $\left(300 \mathrm{MHz}, \mathrm{CDCl}_{3}\right) \delta: 1.99(\mathrm{~s}, 12 \mathrm{H}$, $\left.\mathrm{CH}_{3}\right), 2.25\left(\mathrm{~s}, 12 \mathrm{H}, \mathrm{CH}_{3}\right), 5.78\left(\mathrm{~s}, 4 \mathrm{H}, \mathrm{H}_{o}\right), 6.75(\mathrm{~d}, J=7.5$ $\left.\mathrm{Hz}, 4 \mathrm{H}, \mathrm{H}_{p}\right), 7.13\left(\mathrm{~d}, J=7.5 \mathrm{~Hz}, 4 \mathrm{H}, \mathrm{H}_{m}\right) \cdot E_{1 / 2}(\mathrm{~V}):-1.35$ [Os(VI/V)]. Anal. calcd. for $\mathrm{C}_{32} \mathrm{H}_{36} \mathrm{OOs:} \mathrm{C} \mathrm{59.0,} \mathrm{H} \mathrm{4.9;}$ found: C 58.3, H 4.9 .

\section{Preparation of 4 from 3}

To a solution of $3(0.5 \mathrm{~g}, 0.08 \mathrm{mmol})$ in $\mathrm{CH}_{2} \mathrm{Cl}_{2}(10 \mathrm{~mL})$ was added 1.5 equiv of 3 -chloroperoxybenzoic acid or $t$ $\mathrm{BuOOH}$ at room temperature. The reaction mixture was stirred for $2 \mathrm{~h}$, evaporated to dryness, and subjected to column chromatography (silica gel). The product was eluted with hexane and recrystallized from $\mathrm{CH}_{2} \mathrm{Cl}_{2}$-hexane to give orange crystals ( $80 \%$ yield), which was identified as 4 by ${ }^{1} \mathrm{H}$ NMR spectroscopy and mass spectrometry. Recrystallization of 4 from $\mathrm{CH}_{2} \mathrm{Cl}_{2}$-hexane afforded orange blocks, which were suitable for X-ray diffraction study.

\section{$\left[\mathrm{OsO}\left(\mathrm{C}_{8} \mathrm{H}_{9} \mathrm{O}\right)_{4}\right](5)$}

To a solution of $\left[\mathrm{OsO}_{4}\right](0.5 \mathrm{~g}, 2.0 \mathrm{mmol})$ in $\mathrm{Et}_{2} \mathrm{O}$ $(20 \mathrm{~mL})$ at $-40^{\circ} \mathrm{C}$ was added 7 equiv of 4 -methoxy-2methylphenylmagnesium bromide $(20.6 \mathrm{~mL}$ of a $0.67 \mathrm{M}$ solution in $\mathrm{Et}_{2} \mathrm{O}$ ), and the mixture was slowly warmed to room temperature and stirred for $2 \mathrm{~h}$. The solvent was pumped off and the residue was extracted into $\mathrm{CH}_{2} \mathrm{Cl}_{2}$ in air. Column chromatography (silica gel, eluant: $\mathrm{CH}_{2} \mathrm{Cl}_{2}-\mathrm{Et}_{2} \mathrm{O}$ (1:5)) followed by recrystallization from $\mathrm{CH}_{2} \mathrm{Cl}_{2}$-hexane afforded a brown solid. Yield: $0.25 \mathrm{~g}, 20 \%$. FAB-MS $m / z: 693[\mathrm{M}+1]^{+}$. FT IR $\left(\mathrm{KBr}, \mathrm{cm}^{-1}\right)$ : $982(\mathrm{OsO})$. UV-vis $\left(\mathrm{CH}_{2} \mathrm{Cl}_{2}\right) \lambda_{\max }(\mathrm{nm})$ $\left(\varepsilon_{\max }\left(\mathrm{M}^{-1} \mathrm{~cm}^{-1}\right)\right): 254(26700), 350(11700) .{ }^{1} \mathrm{H}$ NMR $\left(300 \mathrm{MHz}, \mathrm{CDCl}_{3}\right) \delta: 2.28\left(\mathrm{~s}, 12 \mathrm{H}, \mathrm{CH}_{3}\right), 3.76(\mathrm{~s}, 12 \mathrm{H}$, $\left.\mathrm{OCH}_{3}\right), 5.77\left(\mathrm{~d}, J=8.8 \mathrm{~Hz}, 4 \mathrm{H}, \mathrm{H}_{o}\right), 6.41(\mathrm{~d}, J=8.8 \mathrm{~Hz}$, 
Table 1. Crystallographic data for $\left[\mathrm{OsO}\left(\mathrm{C}_{7} \mathrm{H}_{7}\right)_{4}\right](\mathbf{1})$ and $\left[\mathrm{OsO}\left(\mathrm{C}_{8} \mathrm{H}_{9}\right)_{4}\right](4)$.

\begin{tabular}{lll}
\hline Compound & $\mathbf{1}$ & $\mathbf{4}$ \\
\hline Formula & $\mathrm{C}_{28} \mathrm{H}_{28} \mathrm{OOs}$ & $\mathrm{C}_{36} \mathrm{H}_{36} \mathrm{OOs}$ \\
Formula weight & 570.73 & 626.81 \\
Crystal system & Tetragonal & Tetragonal \\
Space group & $P 4 / n$ & $P 4 / n$ \\
$a(\AA)$ & $13.080(1)$ & $13.593(2)$ \\
$c(\AA)$ & $6.6505(5)$ & $7.377(2)$ \\
$V\left(\AA^{3}\right)$ & $1137.9(1)$ & $1363.0(5)$ \\
$Z$ & 2 & 2 \\
$\rho_{\text {calcd }}\left(\mathrm{g} \mathrm{cm}^{-3}\right)$ & 1.666 & 1.527 \\
$\mu($ Mo K $\alpha)\left(\mathrm{cm}^{-1}\right)$ & 56.16 & 46.99 \\
$F(000)$ & 560 & 624 \\
Crystal size (mm) & $0.22 \times 0.12 \times 0.12$ & $0.7 \times 0.6 \times 0.2$ \\
Transmission factor & - & - \\
Total reflections & 6851 & 1636 \\
Unique reflections & - & $1522\left(R_{\text {int }}=0.0221\right)$ \\
No. of observed reflections & $6217(I>1.5 \sigma(I))$ & - \\
No. of variables & 70 & 79 \\
$R(F)$ & 0.022 & - \\
$R_{\mathrm{w}}(F)$ & 0.037 & - \\
$R\left(F^{2}\right)($ all data) & - & 0.0304 \\
$w R_{2}\left(F^{2}\right)($ all data) & - & 0.0842 \\
GoF & 1.38 & 1.088 \\
Max $\Delta / \sigma$ (final cycle) & 0.04 & - \\
Residual density $\left(\mathrm{e} \AA^{-3}\right)$ & $-0.51-1.06$ & $-0.549-1.153$ \\
\hline
\end{tabular}

$\left.4 \mathrm{H}, \mathrm{H}_{m}\right), 6.88\left(\mathrm{~s}, J=8.8 \mathrm{~Hz}, 4 \mathrm{H}, \mathrm{H}_{m}{ }^{\prime}\right) . E_{1 / 2}(\mathrm{~V}):-1.37$ [Os(VI/V)] and 0.93 irreversible [Os(VII/VI)]. Anal. calcd. for $\mathrm{C}_{32} \mathrm{H}_{36} \mathrm{O}_{5} \mathrm{Os}$ : C 57.0, H 5.3; found: C 56.0, H 5.3.

\section{X-ray crystallography}

Pertinent crystallographic data and other experimental details for complexes $\mathbf{1}$ and $\mathbf{4}$ are summarized in Table 1. Data for $\mathbf{1}$ and $\mathbf{4}$ were collected on a Bruker CCD diffractometer and a Siemens P4 diffractometer, respectively, at room temperature using graphite-monochromated Mo $\mathrm{K}_{\alpha}$ radiation $(\lambda$ $=0.71073 \AA$ ). Data were corrected for Lorentz and polarization effects. Absorption corrections are semiempirical based on $\psi$-scan data. Structures $\mathbf{1}$ and $\mathbf{4}$ were solved by direct methods and refined by full-matrix least-squares on $F$ and $F^{2}$, respectively. Hydrogen atoms were included and fixed in their idealized positions (C-H $0.95 \AA$ ). Calculations were carried out using the teXsan (7) (for 1) and SHELXL (8) (for 4) crystallographic software packages. Complete listings of bond lengths and angles, final atomic coordinates of nonhydrogen atoms with thermal parameters, and anisotropic thermal parameters are included as supplementary material. ${ }^{2}$

\section{Results and Discussion}

\section{Synthesis}

The preparations of osmium oxo aryl complexes are summarized in Scheme 1. Wilkinson and co-workers $(4 a)$ first reported the synthesis of $\left[\mathrm{Os}\left(\mathrm{C}_{7} \mathrm{H}_{7}\right)_{4}\right]$ by the reaction of [OsO $\left.\mathrm{O}_{4}\right]$ with $\mathrm{C}_{7} \mathrm{H}_{7} \mathrm{MgBr}$. The osmium tetraaryl was obtained in $29 \%$ yield after extraction into light petroleum and subsequent recrystallization under nitrogen. However, we found that when the reaction mixture was exposed to air and then chromatographed (silica gel) in air, in addition to $\left[\mathrm{Os}\left(\mathrm{C}_{7} \mathrm{H}_{7}\right)_{4}\right]$, the oxo-osmium species $\left[\mathrm{OsO}\left(\mathrm{C}_{7} \mathrm{H}_{7}\right)_{4}\right](\mathbf{1})$ and $\left[\mathrm{OsO}_{2}\left(\mathrm{C}_{7} \mathrm{H}_{7}\right)_{2}\right]$ (2) species were isolated in 13 and $25 \%$ yield, respectively. The relative yields of $\left[\mathrm{Os}\left(\mathrm{C}_{7} \mathrm{H}_{7}\right)_{4}\right], \mathbf{1}$, and $\mathbf{2}$ for the reaction were, however, found to be dependent on reaction conditions, workup procedure, and some unknown factors that have not been optimized yet. It appears that the oxo complexes $\mathbf{1}$ and $\mathbf{2}$ were derived directly from reaction of $\left[\mathrm{OsO}_{4}\right]$ with $\mathrm{C}_{7} \mathrm{H}_{7} \mathrm{MgBr}$, instead of via aerobic oxidation of $\left[\mathrm{Os}\left(\mathrm{C}_{7} \mathrm{H}_{7}\right)_{4}\right]$, because $\left[\mathrm{Os}\left(\mathrm{C}_{7} \mathrm{H}_{7}\right)_{4}\right], \mathbf{1}$, and 2 are all air stable in solution and under chromatographic conditions. Like $\left[\mathrm{Os}\left(\mathrm{C}_{7} \mathrm{H}_{7}\right)_{4}\right](3 a)$, complex 1 exhibits a symmetric ${ }^{1} \mathrm{H}$ NMR spectrum featuring a single ortho-methyl resonance at $\delta 2.32$ at room temperature, indicating that the 2-methylphenyl ligands are free to rotate around the Os- C bonds at the NMR timescale. The UV-vis spectrum of $\mathbf{1}$ in $\mathrm{CH}_{2} \mathrm{Cl}_{2}$ displays absorption bands at ca. $350\left(\varepsilon_{\max }=8700\right.$ $\mathrm{M}^{-1} \mathrm{~cm}^{-1}$ ) and $248 \mathrm{~nm}$ ( $\left.\mathrm{sh}, \varepsilon_{\max }=23000 \mathrm{M}^{-1} \mathrm{~cm}^{-1}\right)$. The former band is tentatively attributed to a charge transfer transition due to the $\mathrm{Os}=\mathrm{O}$ moiety while the latter probably arises from an intraligand transition because a similar absorption was also found for $\left[\mathrm{Os}\left(\mathrm{C}_{7} \mathrm{H}_{7}\right)_{4}\right]$. The IR Os-O

\footnotetext{
${ }^{2}$ Crystal data for $\mathbf{1}$ and $\mathbf{4}$ may be purchased from the Depository of Unpublished Data, Document Delivery, CISTI, National Research Council Canada, Ottawa, ON K1A 0S2, Canada DUD No. 3276. For information on obtaining material electronically go to http://www.nrc.ca/cisti/irm/unpub_e.shtml. This supplementary material has also been deposited with the Cambridge Crystallographic Centre (deposition nos. 148810 and 148809 , respectively), and can be obtained on request from: The Director, Cambridge Crystallographic Centre, University Chemical Laboratory, 12 Union Road, Cambridge, CB2 1EZ, U.K.
} 
Scheme 1.
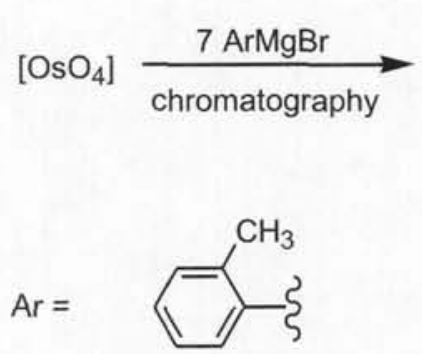<smiles>COc1ccc(S)c(C)c1</smiles>

$3(34 \%)$<smiles>Br[Ge](Br)(Br)[Te]</smiles>

$(10 \%)$

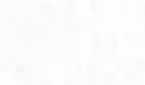

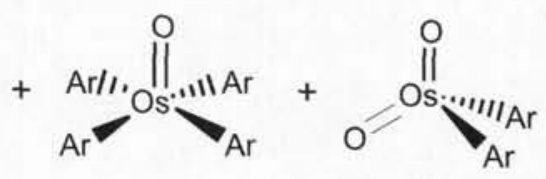

$1(13 \%)$

$2(25 \%)$

$5(20 \%)$

stretching frequency for 1 was observed at $990 \mathrm{~cm}^{-1}$, which is comparable to that for $\left[\mathrm{OsO}\left(\mathrm{CH}_{3}\right)_{4}\right]\left(994 \mathrm{~cm}^{-1}\right)(6 a)$ but is lower than that for $\left[\mathrm{OsO}\left(\mathrm{CH}_{2} \mathrm{SiMe}_{3}\right)_{4}\right]\left(1054 \mathrm{~cm}^{-1}\right)(5 b)$. Complex 2, which presumably has a similar tetrahedral geometry as $\left[\mathrm{OsO}_{2}(\text { mes })_{2}\right](4 a)$, exhibits $\mathrm{v}(\mathrm{OsO})_{\text {as }}$ at 1000 and $980 \mathrm{~cm}^{-1}$. Neither 1 nor 2 reacted with oxygen abstractors such as tertiary phosphines and $\mathrm{Si}_{2} \mathrm{Cl}_{6}$. Attempts to reduce 2 by cobaltocene led to recovery of the starting material.

To further investigate the substituent effect of $\mathrm{Ar}$ on the arylation of $\left[\mathrm{OsO}_{4}\right]$, disubstituted phenyl Grignard were used as the alkylation agents. Treatment of $\left[\mathrm{OsO}_{4}\right]$ with 7 equiv of 2,5-dimethylphenylmagnesium bromide $\left(\mathrm{C}_{8} \mathrm{H}_{9} \mathrm{MgBr}\right)$ in $\mathrm{Et}_{2} \mathrm{O}$ afforded purple $\left[\mathrm{Os}\left(\mathrm{C}_{8} \mathrm{H}_{9}\right)_{4}\right](3)(33 \%)$ and orange $\left[\mathrm{OsO}\left(\mathrm{C}_{8} \mathrm{H}_{9}\right)_{4}\right](4)(4 \%)$, which were separated by column chromatography. On the other hand, reaction of $\left[\mathrm{OsO}_{4}\right]$ with 4-methoxy-2-methylphenylmagnesium bromide $\left(\mathrm{C}_{8} \mathrm{H}_{9} \mathrm{OMgBr}\right)$ in $\mathrm{Et}_{2} \mathrm{O}$ gave the oxo-Os(VI) compound $\left[\mathrm{OsO}\left(\mathrm{C}_{8} \mathrm{H}_{9} \mathrm{O}\right)_{4}\right]$ (5) as the sole isolable product in 20\% yield. Complexes 3-5 are soluble in common organic solvents including hexanes, ether, and methanol. They are air-stable in solution and could be chromatographed in air without decomposition. It appears that the presence of the 5-methyl substituent in the aryl group enhances the production of Os(IV) tetraaryl while the 4-methoxy substituent favors oxo-Os(VI) formation although the origin of such a substituent effect is not well understood. The ${ }^{1} H$ NMR spectrum of $\mathbf{3}$ shows two singlets at $\delta 2.22$ and 2.27 due to the ortho- and meta-methyl protons. Oxidation of 3 with $\left[\mathrm{Ag}\left(\mathrm{CF}_{3} \mathrm{SO}_{3}\right)\right]$ afforded the osmium(V) species $\left[\mathrm{Os}\left(\mathrm{C}_{8} \mathrm{H}_{9}\right)_{4}\right]^{+}$, which exhibits an isotropic EPR signal at $g=2.04$ at $-120^{\circ} \mathrm{C}$. A similar $g$ value was found for the structurally characterized osmium(V) complex $\left[\mathrm{Os}\left(\mathrm{C}_{7} \mathrm{H}_{7}\right)_{4}\right]\left[\mathrm{CF}_{3} \mathrm{SO}_{3}\right](3 \mathrm{~b}, 9)$. Treatment of $\mathbf{3}$ with singleoxygen donors such as 3-chloroperoxybenzoic acid and $t$ $\mathrm{BuOOH}$ gave 4 in good yield. Figure 1 shows a spectral trace for the reaction of 3 with $t$ - $\mathrm{BuOOH}$ in $\mathrm{CH}_{2} \mathrm{Cl}_{2}$. Upon addition of ca. 1 equiv of $t-\mathrm{BuOOH}$, the d-d bands for 3 centered at 447,579 , and $662 \mathrm{~nm}$ disappeared and concomitantly an absorption at $352 \mathrm{~nm}$ attributable to the charge transfer band for $\mathbf{4}$ appeared. The observation of isosbestic points at ca. 325 and $420 \mathrm{~nm}$ suggests that the oxo transfer
Fig. 1. Optical spectral trace for the reaction between $\left[\mathrm{Os}\left(\mathrm{C}_{8} \mathrm{H}_{9}\right)_{4}\right](3)$ and $t-\mathrm{BuOOH}$ in $\mathrm{CH}_{2} \mathrm{Cl}_{2}$.

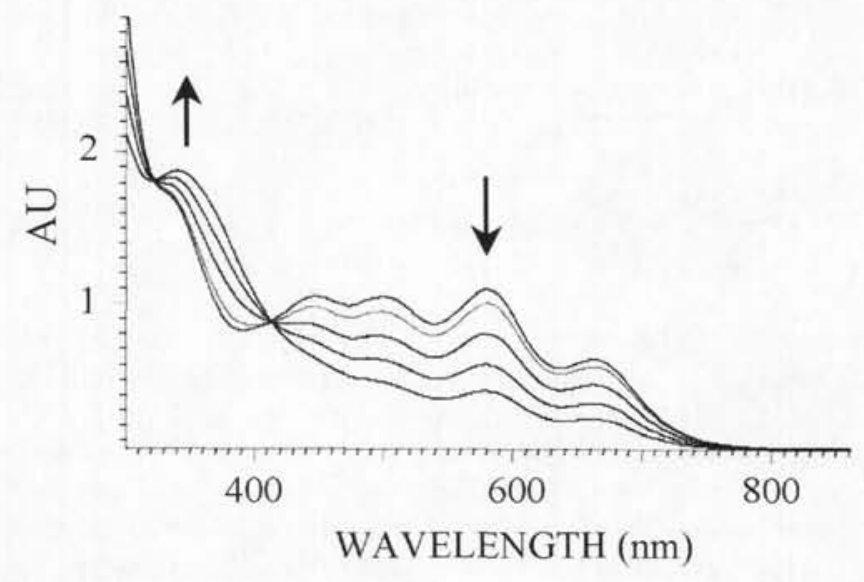

from $t$ - $\mathrm{BuOOH}$ to $\mathbf{3}$ is a clean, single-step process. The charge transfer band for methoxy-substituted $5(385 \mathrm{~nm})$ was found at a longer wavelength relative to those for $\mathbf{4}$ $(352 \mathrm{~nm})$ and $1(350 \mathrm{~nm})$. The ${ }^{1} \mathrm{H}$ NMR spectrum of $\mathbf{4}$ shows two singlets at $\delta 1.99$ and 2.25 due to the meta- and ortho-methyl protons while the methyl and methoxy proton signals for $\mathbf{5}$ were observed at $\delta 2.28$ and 3.76 , respectively. The IR Os-O stretching frequencies for $\mathbf{4}$ and $\mathbf{5}$ (982 and $986 \mathrm{~cm}^{-1}$, respectively) are comparable to that for $\mathbf{1}$.

\section{Crystal structures}

Complexes 1 and 4 have been unambiguously characterized by X-ray crystallography. The corresponding molecular structures with selected bond lengths and angles are shown in Figs. 2 and 3. Complex 1 is isostructural with the previously reported $\operatorname{Re}(\mathrm{VI})$ analogue $\left[\mathrm{ReO}\left(\mathrm{C}_{7} \mathrm{H}_{7}\right)_{4}\right]$, which also exhibits a fourfold molecular symmetry (10). The geometry around osmium in $\mathbf{1}$ and $\mathbf{4}$ is pseudo-square pyramidal with the oxo ligand occupying the apical position. The Os atoms are situated above the $\mathrm{C} 4$ plane with the O-Os-C angles of $110.4(4)$ and $110.82(12)^{\circ}$ for $\mathbf{1}$ and $\mathbf{4}$, respectively, (cf. 
Fig. 2. Molecular structure of $\left[\mathrm{OsO}\left(\mathrm{C}_{7} \mathrm{H}_{7}\right)_{4}\right](\mathbf{1})$. Selected bond lengths and angles are: $\mathrm{Os}(1)-\mathrm{O}(1) 1.652(2)$ and $\mathrm{Os}(1)-\mathrm{C}(1)$ 2.084(1) $\AA$; O(1)-Os(1)-C(1) 110.04(4), C(1)-Os(1)-C(1*) $82.59(3)$, and $\mathrm{C}(1)-\mathrm{Os}(1)-\mathrm{C}\left(1^{*}\right) 137.91(8)^{\circ}$.

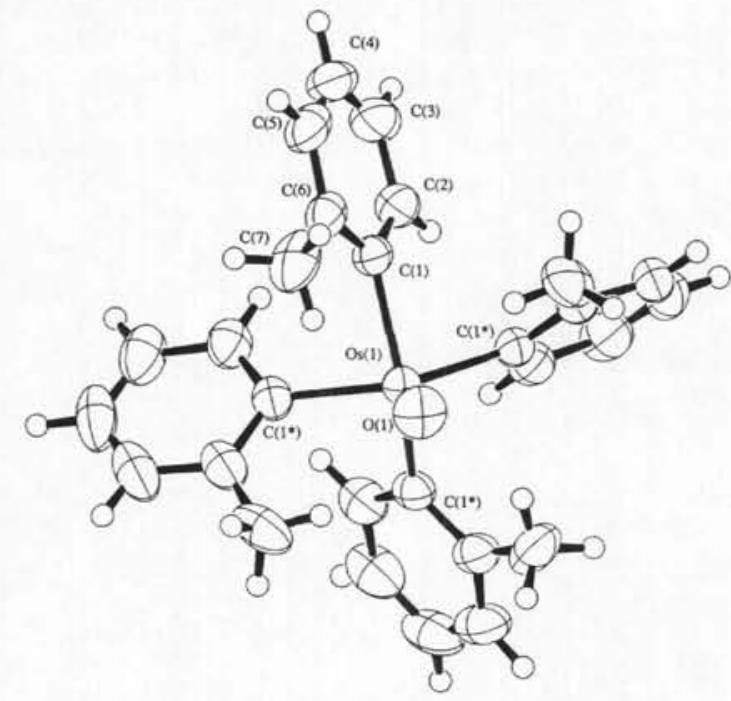

Fig. 3. Molecular structure of $\left[\mathrm{OsO}\left(\mathrm{C}_{8} \mathrm{H}_{9}\right)_{4}\right]$ (4). Selected bond lengths and angles are: $\mathrm{Os}(1)-\mathrm{O}(1) 1.688(7)$ and $\mathrm{Os}(1)-\mathrm{C}(1)$ 2.088(4) $\AA$; O(1)-Os(1)-C(1) 110.82(12), C(1)-Os(1)-C(1B) $82.74(8)$, and C(1)-Os(1)-C(1A) $138.4(2)^{\circ}$.

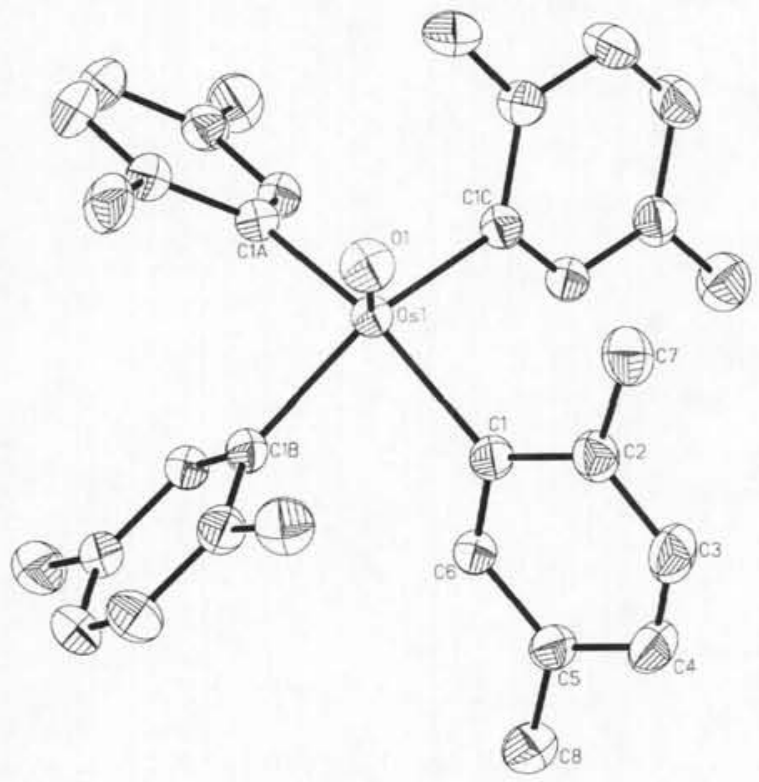

$106.0(2)^{\circ}$ for $\left.\left[\operatorname{ReO}\left(\mathrm{C}_{7} \mathrm{H}_{7}\right)_{4}\right](10)\right)$. Like $\left[\operatorname{ReO}\left(\mathrm{C}_{7} \mathrm{H}_{7}\right)_{4}\right]$, the ortho-methyl groups in $\mathbf{1}$ and $\mathbf{4}$ are found on the same side as the oxo function possibly due to steric reasons. The $\mathrm{Os}-\mathrm{O}$ and average $\mathrm{Os}-\mathrm{C}$ distance for 1 are $1.652(2)$ and 2.084(1) $\AA$, respectively, while those for 4 are $1.688(7)$ and $2.088(4) \AA$, respectively. The $\mathrm{Os}-\mathrm{C}$ distances are comparable to those in $\left[\mathrm{OsO}\left(\mathrm{CH}_{2} \mathrm{SiMe}_{3}\right)_{4}\right]$ (average $2.078 \AA$ ) $(5 b)$ and $\left[\mathrm{ReO}\left(\mathrm{C}_{7} \mathrm{H}_{7}\right)_{4}\right](2.063 \AA)(10)$ but is slightly shorter than that in $\left[\mathrm{Os}\left(\mathrm{C}_{7} \mathrm{H}_{7}\right)_{4}\right]$ (average $1.997 \AA$ ) $(4 a)$. The Os-O distances are short and similar to that in $\left[\mathrm{OsO}\left(\mathrm{CH}_{2} \mathrm{SiMe}_{3}\right)_{4}\right]$ $(1.692(6) \AA)(5 b)$.
Fig. 4. Cyclic voltammogram of $\left[\mathrm{OsO}\left(\mathrm{C}_{8} \mathrm{H}_{9}\right)_{4}\right]$ (4) in $\mathrm{CH}_{2} \mathrm{Cl}_{2}$ at a glassy carbon electrode. Scan rate $=100 \mathrm{mV} \mathrm{s}^{-1}$.

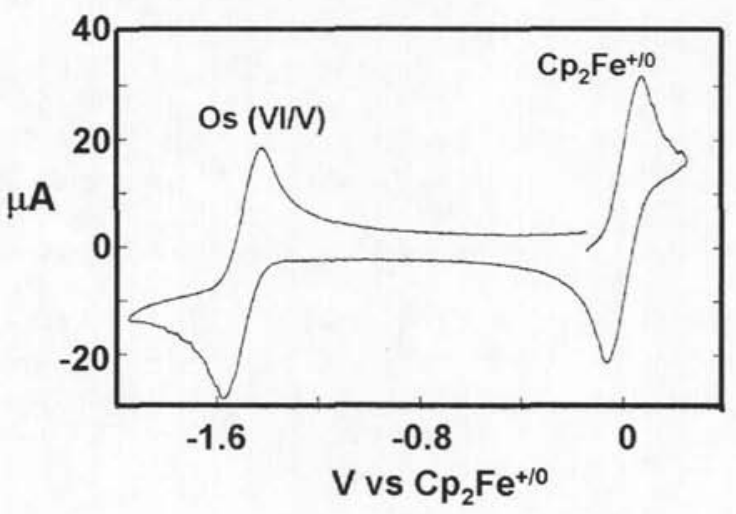

\section{Electrochemistry}

The formal potentials for the osmium aryl complexes have been determined by cyclic voltammetry in $\mathrm{CH}_{2} \mathrm{Cl}_{2}$. The tetraaryl complex 3 exhibits reversible couples at 0.24 and $-1.48 \mathrm{~V}$ vs. $\mathrm{Cp}_{2} \mathrm{Fe}^{+/ 0}$, which are assigned to the metalcentered Os(V/IV) and Os(IV/III) couples, respectively. The $E_{1 / 2}([\mathrm{Os}(\mathrm{V} / \mathrm{IV})])$ for $\mathbf{3}$ is less anodic than that for $\left[\mathrm{Os}\left(\mathrm{C}_{7} \mathrm{H}_{7}\right)_{4}\right](0.33 \mathrm{~V})$ due to inductive effect of meta-methyl substitutents in the aryl groups. The cyclic voltammogram of 4 (Fig. 4) shows a reversible reduction couple at $-1.35 \mathrm{~V}$, which is assigned to the Os(VI/V) couple. Similarly, the Os(VI/V) couples for $\mathbf{1}$ and $\mathbf{5}$ were observed at -1.41 and $-1.37 \mathrm{~V}$, respectively. An irreversible oxidation wave at 0.93 $\mathrm{V}$, which is tentatively assigned to the Os(VII/VI) oxidation, was also found for $\mathbf{5}$. For comparison, the Os(VII/VI) couple for $\left[\mathrm{Os}(\mathrm{O})\left(\mathrm{CH}_{2} \mathrm{SiMe}_{3}\right)_{4}\right]$ was observed at $1.19 \mathrm{~V}$ vs. $\mathrm{Ag} / \mathrm{AgCl}(5 b)$. The dioxo-osmium(VI) complex 2 exhibits the Os(VI/V) couple at $-1.14 \mathrm{~V}$, which is similar to that for $\left.\left[\mathrm{OsO}_{2} \text { (mes) }\right)_{2}\right](-1.28 \mathrm{~V})(4 b)$. In general, the $E_{1 / 2}$ ([Os(VI/V)]) for $\left[\mathrm{OsO}(\operatorname{aryl})_{4}\right]$ are more negative than those for $\left[\mathrm{OsO}_{2}(\operatorname{aryl})_{2}\right]$, indicating that the $\sigma$-aryls are very strong donor ligands.

\section{Conclusions}

In summary, we found that depending on the nature of aryl ligand, reaction of $\left[\mathrm{OsO}_{4}\right]$ with arylmagnesium bromide produced a mixture of osmium(IV) tetraaryl, oxo(tetraaryl)osmium(VI), and dioxo(diaryl)osmium(VI) complexes, which could be separated by column chromatography. It appears that the presence of the 5-methyl substituent in the aryl ligand enhances the formation of Os(IV) tetraaryl while the 4-methoxy substituent favors the formation of $\left[\mathrm{OsO}(\operatorname{aryl})_{4}\right]$. Oxidation of $\left[\mathrm{Os}\left(\mathrm{C}_{8} \mathrm{H}_{9}\right)_{4}\right]$ with 3-choroperoxybenzoic acid gave $\left[\mathrm{OsO}\left(\mathrm{C}_{8} \mathrm{H}_{9}\right)_{4}\right]$ in good yield. The oxo(tetraaryl)osmium(VI) complexes exhibit reversible $\mathrm{Os}(\mathrm{V} / \mathrm{IV})$ couples at ca. $-1.4 \mathrm{~V}$ while the Os(VI/V) couples for dioxodiarylosmium(VI) occur at ca. $-1.1 \mathrm{~V}$ vs. $\mathrm{Cp}_{2} \mathrm{Fe}^{+/ 0}$.

\section{Acknowledgement}

The work described in this paper was supported by a grant from the Research Grants Council of the Hong Kong SAR, China (project no. HKUST 6189/00P). 


\section{References}

1. F. Bottomley and L. Sutin. Adv. Organomet. Chem. 28, 339 (1988), and references cited therein.

2. (a) W.A. Herrmann. J. Organomet. Chem. 500, 149 (1995); (b) W.A. Herrmann. Acc. Chem. Res. 30, 169 (1997).

3. (a) P. Stavropoulos, P.G. Edwards, T. Behling, G. Wilkinson, M. Motevalli, and M.B. Hursthouse. J. Chem. Soc. Dalton Trans. 169 (1987); (b) B.S. McGilligan, J. Arnold, G Wilkinson, B. Hussain-Bates, and M.B. Hursthouse. J. Chem. Soc. Dalton Trans. 2465 (1990).

4. (a) P. Stavropoulos, P.D. Savage, R.P. Tooze, G. Wilkinson, B. Hussain, M. Motevalli, and M.B. Hursthouse. J. Chem. Soc. Dalton Trans. 557 (1987); (b) J. Arnold, G. Wilkinson, B. Hussain, and M.B. Hursthouse. J. Chem. Soc. Dalton Trans. 2149 (1989).
5. (a) A.S. Alves, D.S. Moore, R.A. Andersen, and G. Wilkinson. Polyhedron, 1, 83 (1982); (b) R.W. Marshman, W.S. Bigham, S.R. Wilson, and P.A. Shapley. Organometallics, 9, 1341 (1990).

6. (a) W.A. Herrmann, S.J. Eder, P. Kiprof, K. Rypdal, and P. Watzlowik. Angew. Chem. Int. Ed. Engl. 29, 1445 (1990); (b) W.A. Herrmann, S.J. Eder, P. Kiprof, and P. Watzlowik. J. Organomet. Chem. 428, 187 (1992).

7. TeXsan. Crystal structure package. Molecular Structure Corp., Houston, TX. 1985 and 1992.

8. G.M. Sheldrick. SHELXTL-97 software reference manual. Bruker AXS Inc., Madison, Wisconsin, U.S.A. 1997.

9. J. Arnold, G. Wilkinson, B. Hussain, and M.B. Hursthouse. J. Chem. Soc. Chem. Commun. 1349 (1988).

10. P.D. Savage, G. Wilkinson, M. Motevalli, and M.B. Hursthouse. J. Chem. Soc. Dalton Trans. 669 (1988). 